\title{
Antibody-Dependent Cellular Cytotoxicity in Primary Immunodeficiency Diseases and with Normal Leukocyte Subpopulations
}

\author{
IMPORTANCE OF THE TYPE OF TARGET
}

\author{
S. Ozden Sanal and Rebecca H. Buckley, Departments of Pediatrics and \\ Microbiology and Immunology, the Duke University School of Medicine, \\ Durham, North Carolina 27710
}

\begin{abstract}
A B S T R A C T To gain insight into a possible role for antibody-dependent cell-mediated cytotoxicity in vivo, we examined the ability of leukocytes from 28 patients with primary immunodeficiency and from 20 normal controls to lyse three different types of antibody-coated targets in vitro. Mean cytotoxic indices \pm 1 SD elicited by unfractionated mononuclear cells from normal controls were $28.74 \pm 13.26$ for human HLA antibody-coated lymphocyte targets, 42.79 \pm 8.27 for rabbit IgG antibody-coated chicken erythrocyte targets, and $47.58 \pm 10.34$ for human anti-CD (Ripley)coated $\mathrm{O}+$ erythrocyte targets. Significantly $(P$ $=<0.05$ ) lower than normal mean cytotoxic indices against lymphocyte targets were seen with effector cells from 10 patients with $\mathrm{X}$-linked agammaglobulinemia (3.7 \pm 4.33$)$, in 10 with common variable agammaglobulinemia $(16.05 \pm 7.74)$, in 3 with immunodeficiency with hyper IgM $(18.41 \pm 4.88)$, and in 2 with severe combined immunodeficiency $(3.94 \pm 0.3)$. Antibody-dependent cytotoxicity against chicken erythrocytes was significantly $(P=<0.05)$ lower than normal only in the common variable agammaglobulinemic group (33.33 \pm 12.3$)$ and against human erythrocytes only in the common variable $(34.36 \pm 9.59)$ and hyper $\operatorname{IgM}(27.54 \pm 0.66)$ groups. Rosette and anti-F $\left(\mathrm{ab}^{\prime}\right)_{2}$ depletion studies with normal leukocytes indicated that a nonadherent, nonphagocytic, non-Ig-bearing, non-C receptor-bearing, Fc receptor-bearing lymphocyte was the only effector capable of lysing HLA antibody-coated lymphocyte targets. Patients with in-
\end{abstract}

Dr. Sanal's present address is Hacettepe University, Ankara, Turkey. Dr. Buckley is the recipient of Allergic Diseases Academic Award AI 70830-04.

Received for publication 6 June 1977 and in revised form 22 August 1977. fantile X-linked agammaglobulinemia and severe combined immunodeficiency appear to have a marked deficiency in this type of effector cell function.

\section{INTRODUCTION}

Antibody-dependent cell-mediated cytotoxicity is defined as the lysis of IgG antibody-coated target cells by nonimmune leukocytes bearing membrane receptors for the Fc portion of IgG (1). Although there is evidence that the reaction can be enhanced by the presence of C3b on the target cells (2), this phenomenon can occur in the absence of complement (3). A variety of leukocytes bear receptors for the Fc portion of IgG, including $B(4), K(4,5)$, and $T(6)$ lymphocytes, monocytes (7), and polymorphonuclear cells (8); several of these also have membrane receptors for C3b, namely bone marrow-derived (B) lymphocytes (9), monocytes (9), and polymorphonuclear cells (8). Considerable controversy exists over the capability of these various cell types to serve as effectors in antibody-dependent cellular cytotoxicity. Recent studies suggest that effector cells are different for different types of targets $(10,11)$.

The role of antibody-dependent cell-mediated cytotoxicity in vivo is uncertain, but it is thought to be of possible importance in graft (12) and tumor (13) rejection, in certain autoimmune reactions (14), and in hemolytic disease of the newborn (15). There is little or no information as to its role in host defense, and conflicting results have been reported regarding the capacity of leukocytes from patients with immunodeficiency diseases to serve as effectors in this type of cell lysis (16-18).

In the studies reported here, we attempted to gain further information on the possible role of antibody- 
dependent cellular cytotoxicity in vivo by examining this function in patients with various primary immunodeficiency diseases against three different types of antibody-coated targets. In addition, by using isolated leukocyte subpopulations from normal hosts, we sought to define the types of cells capable of serving as effectors against these three targets.

\section{METHODS}

Patient population. This consisted of 28 patients with well-defined primary immunodeficiency (19), including 10 with $\mathrm{X}$-linked agammaglobulinemia, 10 with common variable or B-lymphocyte agammaglobulinemia, 3 with X-linked immunodeficiency with hyper IgM, 2 with partial DiGeorge syndrome, 2 with severe combined immunodeficiency disease, and 1 with chronic mucocutaneous candidiasis. The clinical, immunologic, and lymphocyte membrane and functional characteristics of many of these patients have been reported $(20,21)$; similar criteria were used to define those not described previously. Normal controls consisted of 20 healthy adults.

Isolation of mononuclear cells. Lymphocytes and monocytes were separated from heparinized venous blood by a modification of the method of Boyum (22). The blood was diluted fourfold in $0.95 \%$ sodium chloride, underlayered with $10 \mathrm{ml}$ of Ficoll-Hypaque, having a specific gravity of 1.078, in 50-ml sterile conical plastic centrifuge tubes (Corning Glass Works, Science Products Div., Corning, N. Y.), and centrifuged for $30 \mathrm{~min}$ at $400 \mathrm{~g}$ at room temperature. The cells recovered at the interface represented greater than $80 \%$ of the mononuclear cells in the whole blood and consisted of lymphocytes predominantly, with 4-29\% monocytes and less than $1 \%$ granulocytes.

Identification of lymphocyte subpopulations. Fc receptor-bearing cells were detected by their ability to form rosettes with human erythrocytes sensitized with either human IgG antibodies derived from Ripley anti-CD serum or rabbit IgG antibodies to human type A erythrocytes. Unless otherwise indicated, Ripley-coated cells were used throughout the study as the antibody-coated erythrocyte indicator, but rabbit IgG-coated human type A erythrocytes were used for this purpose in rosette-depletion studies. 1 vol of packed human $\mathrm{O}+$ erythrocytes in 8 vol of saline was incubated at $37^{\circ} \mathrm{C}$ for $2 \mathrm{~h}$ with $1 \mathrm{vol}$ of Ripley serum, washed four times, and then adjusted to $0.5 \%$ with phosphatebuffered saline containing $2 \%$ fetal calf serum. Rabbit IgGcoated cells were prepared by mixing equal volumes of a $2.5 \%$ suspension of human type A erythrocytes and a subagglutinating dilution of rabbit IgG anti-A antibody, incubating them for $30 \mathrm{~min}$ at $37^{\circ} \mathrm{C}$, washing them four times, and then resuspending them to $0.5 \%$ with phosphate-buffered saline containing $2 \%$ fetal calf serum.

Lymphocytes with receptors for complement, those with surface IgM and (or) IgD, and those forming spontaneous rosettes with sheep erythrocytes were identified and enumerated as described previously (20). In addition, neuraminidase-treated sheep erythrocytes were employed to detect thymus-derived ( $\mathrm{T}$ ) lymphocytes and were prepared as follows: $2 \mu \mathrm{l}$ of neuraminidase (Behring Diagnostics, American Hoechst Corp., Somerville, N. J.) was added to $1 \mathrm{ml}$ of a $1 \%$ sheep erythrocyte suspension in $4 \mathrm{mM}$ bicarbonatebuffered saline containing $3 \mathrm{mM} \mathrm{CaCl} / /$ iter and incubated for $20 \mathrm{~min}$ at $37^{\circ} \mathrm{C}$. The cells were then washed twice and adjusted to $0.5 \%$ for the rosetting studies.

After the above reagents were prepared, they were each mixed with an equal volume (2 drops) of various mononuclear cell suspensions ranging in concentration from 2 to $4 \times 10^{6} / \mathrm{ml}$ in the wells of round-bottom microtiter plates and centrifuged for $6 \mathrm{~min}$ at $800 \mathrm{rpm}$ at room temperature. Rosettes formed with erythrocytes coated with antibody or antibody plus complement were read in $0-6 \mathrm{~h}$ and sheep erythrocyte rosettes in 1-6 h (20). All studies were done in triplicate, and at least 400 cells were counted per well.

Identification and elimination of monocytes. Monocytes were identified by staining for myeloperoxidase activity, using the method of Kaplow (23), and by their ability to ingest latex particles (24). For the latex ingestion studies, 10-20 $\times 10^{6}$ mononuclear cells in $1 \mathrm{ml}$ of phosphate-buffered saline containing $20 \%$ fetal calf serum were incubated with $10 \mu \mathrm{l}$ of latex particles (size $0.3 \mu \mathrm{m}$, Dow Chemical Co., Midland, Mich.) for $20 \mathrm{~min}$ at $37^{\circ} \mathrm{C}$ on a rotating tumbler.

To eliminate monocytes, heparinized blood was either dripped undiluted through a nylon column $(0.7 \mathrm{~g}$ of nylon fiber packed in a 6-in Pasteur pipette) at a rate of approximately $1 \mathrm{drop} / \mathrm{s}$ or diluted to contain approximately $3 \times 10^{6}$ leukocytes $/ \mathrm{ml}$ and incubated with carbonyl iron at a concentration of $4 \mathrm{mg} / \mathrm{ml}$ at $37^{\circ} \mathrm{C}$ for $20-30 \mathrm{~min}$ on a rotating tumbler. After a few minutes were allowed to elapse for sedimentation of the carbonyl iron, the blood was then layered on Ficoll-Hypaque and the iron-laden monocytes were separated by centrifugation.

Depletion of rosette-forming cells by gradient centrifugation. Rosettes of the various types were prepared as described above, except that equal volumes of mononuclear cells $\left(2-4 \times 10^{6} / \mathrm{ml}\right)$ and $1 \%$ suspensions of the various types of erythrocytes were mixed in $15-$ or $50-\mathrm{ml}$ centrifuge tubes and then subjected to Ficoll-Hypaque gradient centrifugation. Lymphocytes were removed from the interface and washed. The sheep erythrocyte rosette pellets were incubated with rabbit anti-sheep erythrocyte hemolysin (Difco Laboratories, Detroit, Mich.) and fresh normal human serum as a source of complement to lyse the red cells; rabbit IgG-coated human A cell rosette pellets were incubated with pony antirabbit IgG and human complement at $37^{\circ} \mathrm{C}$ for $1 / 2 \mathrm{~h}$ to lyse the erythrocytes.

Removal of immunoglobulin-bearing cells by anti-F $\left(a b^{\prime}\right)_{2}$ column depletion. This procedure was performed according to the method of Chess et al. (25) with rabbit anti-F(ab') antibody.

Targets for antibody-dependent cell-mediated cytotoxicity. For these studies, three different types of targets were labeled with $\mathrm{Na}_{2} \mathrm{Cr}^{51} \mathrm{O}_{4}$. The first of these was HLA antibodycoated normal human lymphocytes. Platelets and adherent cells were removed from $10 \mathrm{ml}$ of heparinized blood by passing the blood through a nylon column as described above; the lymphocytes were then obtained by FicollHypaque gradient centrifugation and treated with $2 \mathrm{ml}$ of Tris- $\mathrm{NH}_{4} \mathrm{Cl}$ to lyse any remaining erythrocytes. A suspension of $6-8 \times 10^{6}$ lymphocytes in $0.5 \mathrm{ml}$ of RPMI 1640 media containing $20 \%$ fetal calf serum was labeled with $100 \mu \mathrm{Ci}$ of $\mathrm{Na}_{2} \mathrm{Cr}^{11} \mathrm{O}_{4}$ at $37^{\circ} \mathrm{C}$ for $2 \mathrm{~h}$ in a humidified $5 \% \mathrm{CO}_{2}$ atmosphere with frequent shaking. After being washed four times, the cells were adjusted to a concentration of $1 \times 10^{6} /$ $\mathrm{ml}$ in RPMI 1640 containing 20\% fetal calf serum.

The second type of target was rabbit IgG antibody-coated chicken erythrocytes. To prepare the labeled cells, a suspension of $20 \times 10^{6}$ fresh, thrice-washed chicken erythrocytes in $0.5 \mathrm{ml}$ of RPMI 1640 containing $20 \%$ fetal calf serum was labeled with $100 \mu \mathrm{Ci} \mathrm{Na}_{2} \mathrm{Cr}^{51} \mathrm{O}_{4}$ at $37^{\circ} \mathrm{C}$ for $1 \mathrm{~h}$ with frequent shaking. The cells were then washed four times and adjusted to $5 \times 10^{6} / \mathrm{ml}$.

The final type of target was IgG-coated human erythrocytes. Fresh type $\mathbf{O} \mathbf{R h}+$ erythrocytes were washed three times and 
labeled with $100 \mu \mathrm{Ci}$ of $\mathrm{Na}_{2} \mathrm{Cr}^{51} \mathrm{O}_{4}$ in the same manner as for chicken erythrocytes. One-half of the labeled erythrocyte suspension was sensitized with Ripley anti-CD IgG antibody, as described for preparing the rosette indicator; the cells were then washed and adjusted to $5 \times 10^{6} / \mathrm{ml}$. The other half of the suspension served as the non-antibody-coated control target.

For all targets, the last washes were done just before use in the cytotoxicity assays.

Antibody-dependent cell-mediated cytotoxicity assay. The general features of the assay were modified from Trinchieri et al. (26). When lymphocytes were used as targets, $10 \mu \mathrm{l}$ of either an optimally diluted heat-inactivated human anti-HLA antiserum or RPMI 1640 containing $20 \%$ fetal calf serum were put together with $10 \mu \mathrm{l}$ of the ${ }^{51} \mathrm{Cr}$-labeled cell suspension containing $10^{4}$ lymphocytes into each of the triplicate wells of a round-bottom microtiter (Linbro) plate. The HLA specificities of the targets were always selected to be different from the specificities of the effector cells. When chicken erythrocytes were used as targets, $10 \mu l$ of heat-inactivated rabbit anti-chicken erythrocyte antiserum or medium was added to $10 \mu \mathrm{l}$ of the ${ }^{51} \mathrm{Cr}$-labeled cell suspension containing $5 \times 10^{4}$ erythrocytes in each of triplicate wells. The mixtures were incubated for $30 \mathrm{~min}$ at $4^{\circ} \mathrm{C}$. For human erythrocyte targets, $5 \times 10^{4}$ Ripley sensitized or unsensitized ${ }^{51} \mathrm{Cr}$-labeled erythrocytes were added to the wells with no incubation. Effector cells were then added to the various wells in $100-\mu$ l aliquots, each containing $10^{6}$ cells. Thus, the effector to target cell ratios were 1:100 for the lymphocyte targets and 1:20 for the two erythrocyte targets. These ratios were found to be optimal in preliminary studies with normal control leukocytes. Control wells for all experiments, again in triplicate, included those without effector cells and those without antiserum. The plates were incubated for $4 \mathrm{~h}$ at $37^{\circ} \mathrm{C}$ in a humidified $5 \% \mathrm{CO}_{2}$ atmosphere; then $30 \mu$ l of phosphate-buffered saline were added to each well. The plates were then centrifuged at $400 \mathrm{~g}$ at $4^{\circ} \mathrm{C}$ for $10 \mathrm{~min}$. Supernatant radioactivity was then determined after carefully removing $50 \mu \mathrm{l}$ from the side of each well with an Eppendorf pipette and disposable tip (Brinkmann Instruments, Inc., Westbury, N. Y.) and counting the aliquots in a gamma spectrometer (Beckman Instruments Inc., Fullerton, Calif.). The counts per minute for each well were multipled by 3 to obtain total release. The mean counts per minute, standard deviation, and standard error were determined for each triplicate set and the percentage of specifically released ${ }^{51} \mathrm{Cr}$ was calculated as follows:

Experimental release - spontaneous release

Total releasable cpm - spontaneous release

$=$ Cytotoxic Index

Only cytotoxic indices of $10 \%$ or greater were considered positive.

\section{RESULTS}

Antibody-dependent cytotoxicity by normal unfractionated mononuclear cells. The mean cytotoxic indices obtained when normal non-monocyte-depleted Ficoll-Hypaque-purified mononuclear cells were

TABLE I

Mean Antibody-Dependent Cellular Cytotoxicity Indices* for Normal Controls and Immunodeficient Patients with Three Different Types of Target Cells

\begin{tabular}{|c|c|c|c|c|c|c|}
\hline \multirow[b]{2}{*}{ Subjects } & \multicolumn{2}{|c|}{ Lympht } & \multicolumn{2}{|c|}{ CRBC } & \multicolumn{2}{|c|}{ HRBC } \\
\hline & $\mathrm{nt}$ & CIt & $n !$ & CIt & $n \ddagger$ & CIt \\
\hline Normals & 10 & $\begin{array}{r}28.74 \\
\pm 13.26\end{array}$ & 14 & $\begin{array}{r}42.79 \\
\pm 8.27\end{array}$ & 11 & $\begin{array}{r}47.58 \\
\pm 13.26\end{array}$ \\
\hline $\begin{array}{l}\text { X-linked } \\
\text { agammaglobulinemia }\end{array}$ & 10 & $\begin{aligned} & 3.70 \oint \\
\pm & 4.33\end{aligned}$ & 9 & $\begin{array}{r}44.17 \\
\pm 10.56\end{array}$ & 9 & $\begin{array}{r}41.15 \\
\pm 10.34\end{array}$ \\
\hline $\begin{array}{l}\text { Common variable } \\
\text { agammaglobulinemia }\end{array}$ & 10 & $\begin{array}{l}16.05 \S \\
\pm 7.74\end{array}$ & 7 & $\begin{aligned} & 33.33 \S \\
\pm & 12.3\end{aligned}$ & 9 & $\begin{array}{l}34.36 \S \\
\pm 9.59\end{array}$ \\
\hline X-linked hyper IgM & 3 & $\begin{array}{l}18.41 \oint \\
\pm 4.88\end{array}$ & 3 & $\begin{array}{r}42.92 \\
\pm 8.18\end{array}$ & 3 & $\begin{array}{l}27.54 \S \\
\pm 0.66\end{array}$ \\
\hline DiGeorge & 2 & $\begin{array}{l}41.43 \S \\
\pm 5.43\end{array}$ & 1 & 45.3 & 1 & 33.60 \\
\hline $\begin{array}{l}\text { Severe combined } \\
\text { immunodeficiency }\end{array}$ & 2 & $\begin{array}{l}3.94 \S \\
\pm .30\end{array}$ & 1 & 52.36 & 1 & 25.59 \\
\hline $\begin{array}{l}\text { Chronic mucocuta- } \\
\text { neous candidiasis }\end{array}$ & 1 & 23.94 & 1 & 一 & 1 & - \\
\hline
\end{tabular}

$* \pm 1 \mathrm{SD}$.

\$ Lymph = HLA antibody-coated lymphocyte target; CRBC = chicken erythrocytes coated with rabbit IgG; HRBC = human erythrocytes coated with Ripley IgG; $n=$ number; $\mathrm{CI}=$ cytotoxic indices.

$\$$ Value significantly different $(P=<0.05)$ from normal mean when compared in Student's $t$ test. 
tested against the three different types of target cells are presented in Table $I$ and shown in Fig. 1. When normal rabbit or human sera were used instead of the various target-specific antisera, no significant ${ }^{51} \mathrm{Cr}$ release was observed. The coefficients of variation for day-to-day variability in the cytotoxic indices for the three types of targets, as determined using a single donor's effector cells on 14, 6, and 8 days against lymphocyte, chicken erythrocyte, and human erythrocyte targets, respectively, were $22.2,21$, and $31.5 \%$.

Antibody-dependent cytotoxicity by mononuclear cells from immunodeficient patients. When antibodydependent cytotoxicity was examined in 10 patients with X-linked agammaglobulinemia and in 10 with common variable agammaglobulinemia, unfractionated mononuclear cells from both patient groups lysed the two erythrocyte targets to a significant degree (Table I and Fig. 1). In contrast, mononuclear cells from the $\mathrm{X}$-linked agammaglobulinemics did not cause significant ${ }^{51} \mathrm{Cr}$ release from HLA antibody-coated lymphocytes, whereas cells from patients with the common variable form did. It should be noted that cells from a number of individual common variable agammaglobulinemic patients had normal cytotoxic activity against all three types of targets, whereas only one of the X-linked patients had a cytotoxic index (11.28) greater than $10 \%$ against lymphocyte targets. When the group means were compared with those from the normal subjects by Student's $t$ test, however, the means for the common variable group were significantly $(P$

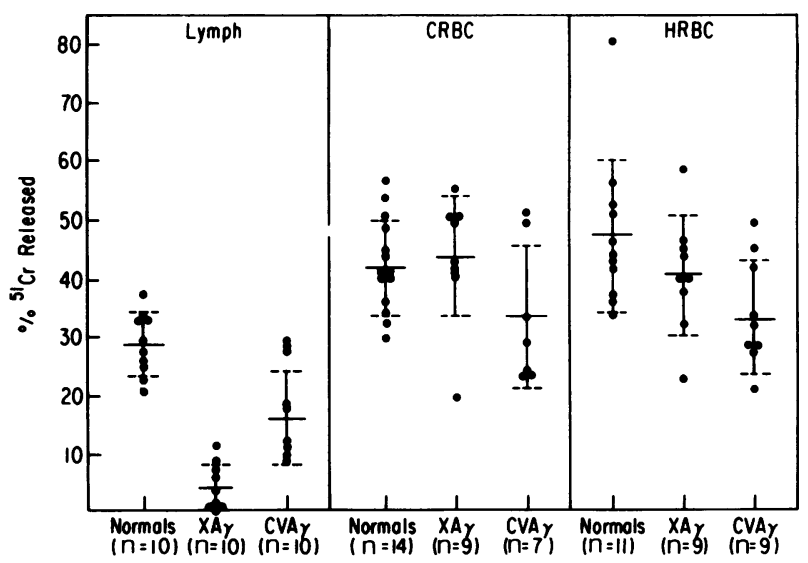

Figure 1 Comparison of antibody-dependent cellular cytotoxicity against three different antibody-coated targets by mononuclear cells from X-linked (XAy) and common variable (CVA $\gamma$ ) agammaglobulinemic patients and normal controls. Lymph refers to human HLA antibody-coated lymphocyte targets, CRBC to rabbit antibody-coated chicken erythrocytes, and HRBC to Ripley anti-CD-coated human $\mathrm{O}^{+}$ erythrocyte targets. The dots represent the cytotoxic indices for individual patients, the solid horizontal lines the group means, and the dashed lines \pm 1 SD. $n=$ the number in each group.
$=<0.05)$ lower than normal for all three targets (Table I). Only the mean cytotoxic index against lymphocyte targets differed significantly from the normal group mean for the $\mathrm{X}$-linked agammaglobulinemic group.

Results of studies with effector cells from two infants with severe combined immunodeficiency are shown in Fig. 2, and the cytotoxic indices against the three different types of targets are presented in Table I. No significant ${ }^{51} \mathrm{Cr}$ release was obtained when unfractionated mononuclear cells from one infant were tested against HLA antibody-coated lymphocyte targets in five separate experiments, nor did cells from the other patient cause significant release in the only experiment in which his cells were tested. On the other hand, mononuclear cells from one patient caused significant release of ${ }^{51} \mathrm{Cr}$ from both types of red cell targets. Previous studies from this laboratory had shown that patient 1 had $4 \%$ and patient 2 had $3 \% \mathrm{Fc}$ receptor-bearing cells in their FicollHypaque-purified, macrophage-depleted mononuclear cells. Comparison of the mean cytotoxic index against lymphocyte targets for the infants with severe combined immunodeficiency with that of the normal group by Student's $t$ test revealed it to be significantly lower $(P=<0.05)$ than normal.

Mean cytotoxic indices for the three patients with hyper IgM, the two with DiGeorge syndrome, and the one with chronic mucocutaneous candidiasis are presented in Table I. Student $t$ tests comparing the means revealed the mean cytotoxic indices for the three hyper IgM patients against the lymphocyte and human erythrocyte targets to be significantly $(P=<0.05)$ lower than normal and the mean cytotoxic index for the two DiGeorge patients against lymphocyte targets to be significantly $(P=<0.05)$ higher than normal.

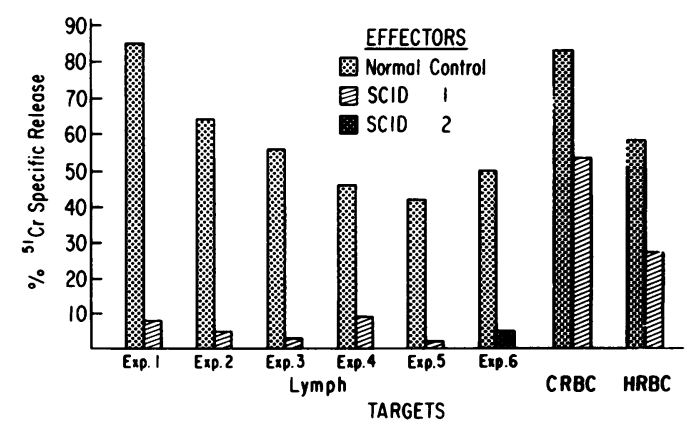

Figure 2 Comparison of antibody-dependent cellular cytotoxicity by mononuclear cells from two infants with severe combined immunodeficiency (SCID) against the same three targets shown in Fig. 1. Patient 1 was studied over a 10mo period against a variety of different HLA antibodycoated lymphocyte targets but on only one occasion against the erythrocyte targets. Patient 2 was studied only one and only against lymphocyte targets at the age of $10 \mathrm{mo}$. 
Effect of depletion of adherent or phagocytic cells on antibody-dependent cell lysis by mononuclear cells. Because Ficoll-Hypaque-purified mononuclear cell suspensions from both normal and immunodeficient subjects were noted to vary in their monocyte content, and because some of the X-linked agammaglobulinemic patients' mononuclear cell suspensions were observed to have very high (up to $63 \%$ ) percentages of cells staining with myeloperoxidase, a series of studies with both normal and immunodeficient subjects' cells was designed to determine what effect an excessive number of monocytes might have on effector cell function. Mean percentages of myeloperoxidase-

TABLE II

Effect of Adherent Cell Depletion on Percentage of Fc Receptor Cells and Cytotoxicity with Mononuclear Cell Suspensions from Immunodeficiency Patients

\begin{tabular}{llll}
\hline Type of donor & $\begin{array}{c}\text { Percentage of cells } \\
\text { positive for* }\end{array}$ & $\begin{array}{c}\text { Cytotoxicity } \\
\text { index against } \\
\text { lymphocyte } \\
\text { target }\end{array}$ \\
\hline
\end{tabular}

Normal control 1

Untreated mononuclear cells

$14.5 \quad 11.2$

37.36

Column treated cells

$0.5 \quad 8.9$

50.28

X-linked agammaglobulinemic 1

Untreated mononuclear cells

Column treated cells

17

7.01

$0.4 \quad 4.05$

10.34

$\mathrm{X}$-linked agammaglobulinemic 2

Untreated mononuclear cells

9

Column treated cells

0.66

Common variable agammaglobulinemic 1

Untreated mononuclear cells

$15.4 \quad 18$

10.02

Column treated mononuclear cells

Hyper IgM 1

Untreated mononuclear cells

$\begin{array}{rrr}23.7 & - & 20.24 \\ 5.9 & - & 37.47 \\ & & \\ 17.4 & 29 & 22.11 \\ - & - & 31.74\end{array}$

Column treated mononuclear cells

Hyper IgM 2

Untreated mononuclear cells

* POX = myeloperoxidase positive cells; HEA = cells rosetting with human $\mathrm{O}+$ erythrocytes coated with Ripley IgG anti-CD antibody.

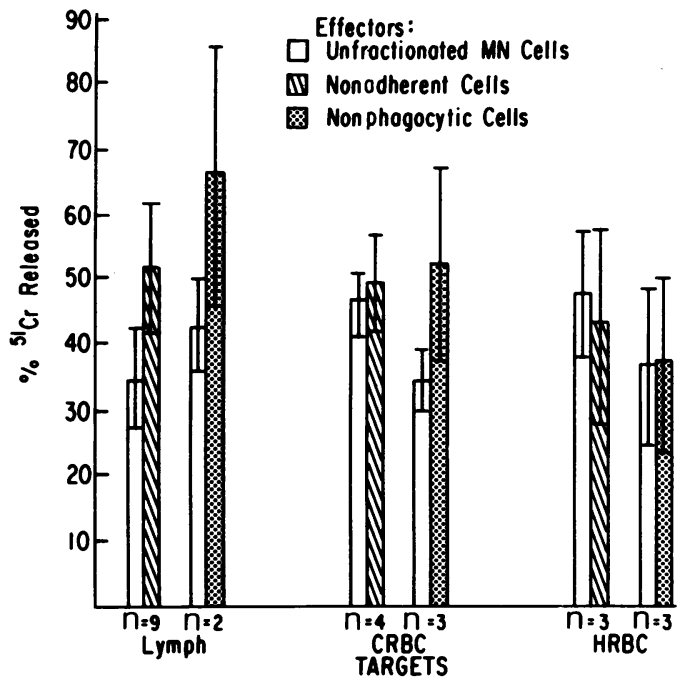

FIGURE 3 The effect of depletion of adherent or phagocytic cells on antibody-dependent cellular cytotoxicity against various targets by normal mononuclear (MN) cells. Refer to legend to Fig. 1 for description of targets. $n$ refers to the number of experiments in which the activity of the particular type of effector cell population was evaluated. The vertical lines represent $\pm 1 \mathrm{SD}$ of the mean $\%{ }^{51} \mathrm{Cr}$ released (represented by the top of each bar) in all of the experiments done with that particular type of effector.

positive cells detected in Ficoll-Hypaque-purified cells from 14 normal controls, $9 \mathrm{X}$-linked agammaglobulinemics, and 10 common variable agammaglobulinemics were $7.54 \pm 1.07,20.96 \pm 16.69$, and 10.32 \pm 3.26 , respectively. Although the mean is higher for the X-linked agammaglobulinemic group than for the other two, the difference is not statistically significant because of the large standard deviation for that group.

Neither nylon column nor carbonyl iron treatment significantly lowered the percentage of cells rosetting with Ripley IgG-coated human erythrocytes, yet it eliminated a majority of the monocytes (Table II). Moreover, antibody-dependent cellular cytotoxicity increased significantly $(P=<0.01)$ against lymphocyte targets after both adherent and phagocytic cell removal and remained essentially unchanged against the two types of erythrocyte targets (Fig. 3). These studies indicate that $F c$ receptor-bearing lymphocytes can serve as effector cells against all three types of targets. As shown in Table II, however, removal of essentially all myeloperoxidase-positive cells from Ficoll-Hypaque-purified cells of two patients with $\mathrm{X}$ linked agammaglobulinemia by nylon column treatment did not significantly improve the cytotoxic activity of those cells against lymphocyte targets, whereas removal of myeloperoxidase-positive cells from mononuclear cells of one patient with common variable agammaglobulinemia and two with hyper IgM increased this activity in the remaining cells, 
just as it did in normals. These results suggest that $\mathrm{X}$-linked agammaglobulinemic mononuclear cells are functionally deficient in a subpopulation of lymphocytes capable of lysing antibody-coated lymphocyte but not antibody-coated erythrocyte targets. The impaired effector cell function against lymphocyte targets does not appear to be due to a lack of $\mathrm{Fc}$ receptorbearing lymphocytes, since cells forming rosettes with Ripley IgG-coated human erythrocytes have been found in normal or near normal quantity in all X-linked agammaglobulinemia monocyte-depleted mononuclear cell preparations examined thus far.

Effect of sheep erythrocyte rosette depletion and function of sheep erythrocyte rosette-forming cells in antibody-dependent cellular cytotoxicity. In a further effort to characterize the cytotoxic effector cells for the three types of antibody-coated targets employed in these studies, sheep erythrocyte rosettedepletion studies were performed. As shown in Fig. 4, when monocytes were depleted from normal mononuclear cells before rosetting them with sheep erythrocytes, lymphocytes forming such rosettes did not cause significant ${ }^{51} \mathrm{Cr}$ release from any of the three types of targets. In contrast, if sheep erythrocyte rosette-forming cells were prepared from unfractionated mononuclear cells, the pelleted cells were able to effect significant lysis of both red cell targets; such cells were shown by myeloperoxidase staining to contain significant numbers of monocytes (around 5\%). In both situations, the non-rosetteforming cells were able to serve as effectors against each of the three types of targets, and this activity was often greatly enhanced in the depleted population (Fig. 4).

Effect of depletion of cells bearing the complement receptor on antibody-dependent cellular cytotoxicity. The results of experiments in which mono-

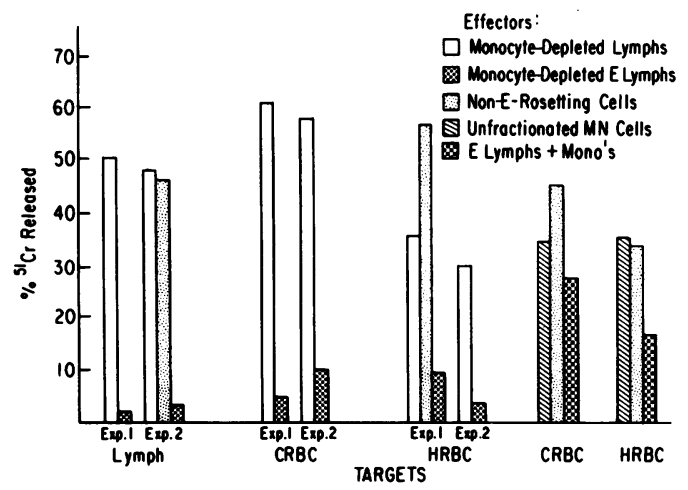

FIGURE 4 Effect of sheep erythrocyte (E) rosette-depletion and function of E-rosetting cells in cytotoxicity experiments employing the same three types of antibody-coated targets described in the legend to Fig. 1. The source of the mononuclear cells for these experiments was normal subjects. nuclear cells forming rosettes with erythrocytes coated with IgM antibody and complement were depleted and the remaining cells tested against all three types of targets are presented in Fig. 5. The activity in the population depleted of complement receptor-bearing cells was comparable to that of the unfractionated mononuclear cell suspension against all targets.

Effect of depletion of immunoglobulin-bearing cells on antibody-dependent cellular cytotoxicity. As shown in Table III, depletion of a majority of immunoglobulin-bearing cells by passing Ficoll-Hypaque mononuclear cells over an anti- $\mathrm{F}\left(\mathrm{ab}^{\prime}\right)_{2}$ column had little effect on the cytotoxic activity of the remaining cells, regardless of the type of antibody-coated target, except that it was increased for the lymphocyte target. This was true for both normal and DiGeorge cells. The depleted populations still had $\approx 2 \%$ immunoglobulinbearing cells, however, and contained from 2.3 to $11.9 \%$ monocytes and from 6.8 to $16 \%$ cells forming rosettes with Ripley IgG-coated human erythrocytes.

Effect of depletion of cells bearing the Fc receptor. In contrast to the results of all other types of depletion studies, removal of cells forming rosettes with IgG-coated erythrocytes had a profound effect on the cytotoxic activity of the remaining mononuclear cells against lymphocyte targets (Fig. 6). Specific ${ }^{51} \mathrm{Cr}$ release ranged only from 4.3 to $11 \%$ when nonrosette-forming cells were tested against HLA antibody-coated lymphocyte targets in four separate experiments. Cytotoxic activity was detected with these cells against both erythrocyte targets, however, but this could have been due to residual monocytes found in concentrations of 3.5 to $6 \%$ in all depleted populations tested. Cells rosetting with IgG-coated erythrocytes were able to effect lysis against all three targets, but the activity of the cells against the

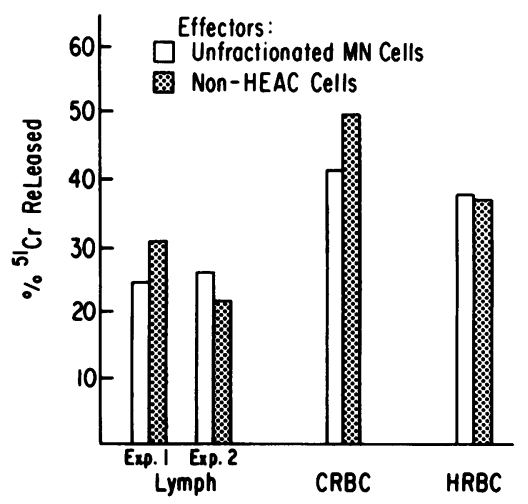

FIGURE 5 Effect of depletion of complement receptor-bearing lymphocytes on antibody-dependent cellular cytotoxicity against various targets. See legend to Fig. 1 for description of targets. HEAC, human erythrocytes coated with rabbit IgM antibody and mouse complement; $M N$, mononuclear cells. 
TABLE III

Characteristics of Mononuclear Cell Populations and ADCC Activity

after Anti-F $\left(a b^{\prime}\right)_{2}$ Column Treatment

\begin{tabular}{|c|c|c|c|c|c|c|c|}
\hline \multirow[b]{2}{*}{ Donor } & \multirow{2}{*}{$\begin{array}{l}\text { Mononuclear } \\
\text { cell population }\end{array}$} & \multicolumn{4}{|c|}{$\begin{array}{l}\text { Percentages of cells } \\
\text { positive for }\end{array}$} & \multicolumn{2}{|c|}{ Cytotoxicity indices } \\
\hline & & POX* & $\mathbf{E}^{*}$ & HEA* $^{*}$ & SIg* & Lymph* & CRBC* \\
\hline Normal & $\begin{array}{l}\text { Unfractionated } \\
\text { mononuclear cells }\end{array}$ & 15 & 57.7 & 7.9 & - & 25.9 & 47.68 \\
\hline Normal & SIg- & 6.5 & 69.6 & 11.1 & - & 43.15 & 50.67 \\
\hline Normal & SIg- & 2.3 & 68.4 & 6.8 & 2 & 37.03 & 50.18 \\
\hline DiGeorge & SIg- & 11.9 & 53.5 & 16 & 2 & 57.47 & 63.4 \\
\hline
\end{tabular}

* $\mathrm{POX}=$ myeloperoxidase staining; $\mathrm{E}=$ sheep erythrocyte rosetting; $\mathrm{HEA}=$ rosetting with human erythrocytes coated with Ripley IgG; SIg = surface immunoglobulin; Lymph $=$ HLA antibody-coated lymphocyte targets; CRBC $=$ chicken erythrocytes coated with rabbit IgG antibody.

lymphocyte targets was not as great as that of the unfractionated cells. This was possibly due to the fact that red cells were not successfully removed in the lysis procedure.

\section{DISCUSSION}

We undertook the evaluation of antibody-dependent cellular cytotoxicity in patients with well-defined host deficits, not only to obtain base-line information on this function in various immunodeficiency diseases, but also to gain insight into the possible relevance of this phenomenon in vivo. Different conclusions were reached regarding this function in immunodeficient patients in the limited number of published studies

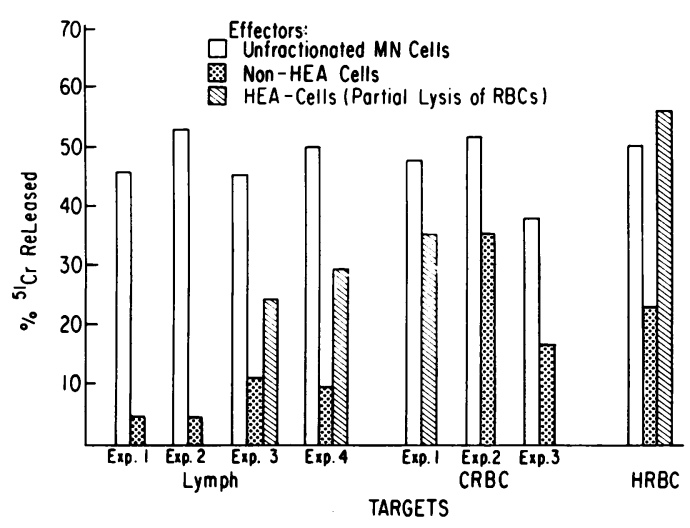

Figure 6 Effect of depletion of lymphocytes forming rosettes with human erythrocytes coated with IgG antibody (HEA) on antibody-dependent cellular cytotoxicity against various targets. See legend to Fig. 1 for description of targets. The rosette-forming cells still had some erythrocytes attached at the time of the cytotoxicity studies, because only partial lysis was achieved with the pony anti-rabbit IgG and human complement. to date (16-18). Blaese et al. (16), using normal human lymphocytes coated with HLA antibody as targets, found four Wiskott-Aldrich patients' mean antibody-dependent cellular cytotoxicity to be $95 \%$ of the normal mean, whereas the mean cytotoxicity of eight hypogammaglobulinemic patients was only $50 \%$ (range $25-95 \%$ ) of normal. The authors speculated, primarily on the basis of these observations and their finding that cancer and T-cell-deficient intestinal lymphangiectasia patients also had normal or increased antibody-dependent cytotoxicity function, that cytotoxicity against that type of antibody-coated target was probably mediated by a B or some other non-T cell. Rachelefsky et al. (18) also found low cytotoxic activity with five agammaglobulinemic patients' lymphocytes when they were tested against HLA antibody-coated normal human lymphocytes and concluded that deficient antibody-dependent cellular cytotoxicity correlated with decreased numbers of B cells. In contrast, Wisloff and Froland (17), in studying the cytotoxic activity of agammaglobulinemic patients' lymphocytes against antibody-coated chicken erythrocyte targets, found normal activity and concluded that such function was independent of the presence or number of B cells. The studies presented here point up the crucial role of the type of target in assessing antibodydependent cellular cytotoxicity $(10,11)$ and help explain conflicting findings in various published reports as to effector cell identity. Few studies have compared effector activity of mononuclear cells from either patients or normals against more than one type of target, and we could find none that evaluated all three of the types of targets used in the present investigation. Nelson et al. (11), in studies comparing normal effector cell function against rabbit antibody-coated Chang liver cells and guinea pig antibody-coated chicken 
erythrocytes, found that cytotoxicity was mediated against Chang cells only by surface immunoglobulinnegative lymphocytes, but that lysis of chicken erythrocyte targets was effected by polymorphonuclear leukocytes, macrophages, and immunoglobulin-negative lymphocyte subpopulations. The findings for chicken erythrocyte targets are in keeping with those in this report, and their results with Chang cells parallel those with HLA antibody-coated lymphocytes in the present study.

Although cytotoxic activity was significantly ( $P$ $=<0.05)$ lower than normal against lymphoid targets for most of the agammaglobulinemic patients in the present study, the results appear to differentiate patients with X-linked agammaglobulinemia from those with common variable agammaglobulinemia by the more severe degree of impairment in K-cell function in the former. X-linked agammaglobulinemic patients lack immunoglobulin-bearing B lymphocytes, whereas common variable agammaglobulinemic patients usually have a normal or near normal number of such cells (20). These observations plus the significantly higher than normal mean cytotoxic index of the two DiGeorge patients against lymphocyte targets tend to support the postulate of Blaese et al. (16) and Rachelefsky et al. (18) that antibody-dependent cellular cytotoxic function correlates with the number of B cells. This hypothesis fails, however, in the case of the two infants with severe combined immunodeficiency, one of whom had $69 \%$ and the other $12 \%$ surface immunoglobulin in M- and D-bearing cells (21) but neither of whose cells effected significant lysis of antibodycoated lymphocyte targets. These findings are of interest in view of current differences of opinion as to the nature of the $\mathrm{K}$ lymphocyte. As in the present study, Brier et al. (27) found the human lymphocyte responsible for lysis of antibody-coated lymphocyte targets in a subpopulation of nonadherent cells expressing neither the receptor for sheep erythrocytes nor surface immunoglobulin. Later work from that laboratory, however, indicated that when that population of cells was held in culture for 6 days, immunoglobulin was synthesized by the cells, suggesting that they were B-cell precursors (28). Their additional finding that antibody-dependent cellular cytotoxicity could be abrogated by treatment of such a cell population with an anti-Ia antiserum appeared to provide further evidence for a B-cell origin of the effector lymphocyte in antibody-dependent lysis of nucleated target cells (28). Since interaction of whole anti-Ia antibodies or Ia antibodies complexed with antigen with $\mathrm{Fc}$ receptors on $\mathrm{K}$ lymphocytes could have led to abrogation of antibody-dependent cytotoxicity, however, this conclusion remains open to question. In this regard, Nelson et al. (29) have re- cently reported that $\mathrm{Fc}$ receptor-bearing, surface immunoglobulin-negative lymphocytes which mediate cytotoxicity against antibody-coated Chang liver cells lack B-cell alloantigens.

The subpopulation of normal lymphocytes mediating cytotoxicity against HLA antibody-coated lymphocyte targets in this study had surface membrane characteristics identical with those of the subpopulation found to effect lysis of Chang targets by Nelson et al. (11). The rosette-depletion studies provide strong evidence that the antibody-dependent cytotoxicity effector cell for HLA antibody-coated lymphocyte targets is an $\mathrm{F}_{\mathrm{c}}$ receptor-bearing lymphocyte. The present study, as well as the earlier studies of Wisloff and Froland (17) and the more recent ones of Papamichael and Temple (30), Nelson et al. (11), and Pape et al. (31), demonstrate that there is no requirement for immunoglobulin-positive lymphocytes to obtain lysis of either nucleated or nonnucleated antibody-coated targets. Work by others (32) has shown that B lymphocytes have Fc receptors for IgG, but these can usually be demonstrated only by fluorosceinated aggregated IgG or immune complexes. In contrast, Ripley-coated human $\mathrm{O}+$ erythrocytes appear to form rosettes only with lymphocytes having highavidity $\mathrm{F}_{\mathrm{c}}$ receptors and lacking conventional $\mathrm{T}$ - and B-cell markers (5). Results of depletion of this latter population in the present investigation, as well as in studies of Wisloff et al. (5) and Pape et al. (31), confirm that the presence of this receptor is a prerequisite for antibody-dependent cellular cytotoxicity effector activity. The present investigation also confirmed the findings of Nelson et al. (11) that lymphocytes bearing the complement receptor are not required for lysis of antibody-coated nucleated targets, and of Wisloff et al. (5) and Greenberg et al. (33) that the lymphocyte mediating this function does not bear T-cell markers. Moreover, like Nelson et al. (11), we found that purified E-rosetting cells are incapable of effecting cell lysis. While no purified preparations of monocytes were used in these studies, populations of mononuclear cells depleted of Ripley rosetting lymphocytes still contained up to $5 \%$ myeloperoxidase-positive cells; such suspensions were unable to effect greater than $10 \%{ }^{51} \mathrm{Cr}$ release from lymphocyte targets but still caused significant lysis of both red cell targets. Depletion of monocytes increased the cytotoxic function of the remaining cells against lymphocyte targets but not against the two erythrocyte targets, confirming that $\mathrm{K}$ lymphocytes can lyse all three types of targets.

The absence of cytotoxic activity against nucleated targets, despite the presence of cells which formed rosettes with Ripley IgG-coated human erythrocytes among macrophage-depleted lymphocyte populations 
from the patients with $\mathrm{X}$-linked agammaglobulinemia and severe combined immunodeficiency in the present study $(20,21)$ and from patients with chronic lymphocytic leukemia evaluated by Gale et al. (34), is evidence that the mere presence of $\mathrm{Fc}$ receptor-bearing lymphocytes is insufficient for antibody-dependent cellular cytotoxicity to occur. Unfortunately, the finding of severely impaired K-lymphocyte function in infants with severe combined immunodeficiency does not add much to the understanding of either the nature of the $\mathrm{K}$ cell, since all lymphocyte function is lacking in such patients, or of the relevance of antibodydependent cellular cytotoxicity to host defense, since this defect is invariably fatal unless corrected. The finding of an equally severe K-lymphocyte impairment in patients with X-linked agammaglobulinemia who have normal T-cell function but lack surface immunoglobulin-bearing B lymphocytes may be a clue that antibody-dependent cellular cytotoxicity does have an in vivo protective role. Patients with $\mathrm{X}$-linked agammaglobulinemia have recently been shown to have a high propensity to develop persistent enterovirus meningoencephalitis, ultimately leading to death, despite adequate humoral replacement therapy (35). This has not been observed thus far in comparably treated patients with common variable agammaglobulinemia.

\section{ACKNOWLEDGMENTS}

We are indebted to Dr. Euripedes Ferreira for performing the antibody-dependent cellular cytotoxicity studies with the severe combined immunodeficiency disease lymphocytes and for his early guidance in the technical aspects of this assay. We are also grateful to Mrs. Lora Whitfield for her excellent secretarial assistance with the manuscript.

This work was supported in part by a fellowship grant to Dr. Sanal from the Department of Pediatrics, Hacettepe University, Ankara, Turkey, and a grant from the General Clinical Research Centers Program (RR-30) of the Division of Research Resources, National Institutes of Health.

\section{REFERENCES}

1. Moller, E. 1965. Contact-induced cytotoxicity by lymphoid cells containing foreign isoantigens. Science (Wash. D. C.). 147: 873-879.

2. Perlmann, P., H. Perlmann, and H. J. Müller-Eberhard. 1975. Cytolytic lymphocytic cells with complement receptor in human blood. Induction of cytolysis by IgG antibody but not by target cell-bound C3. J. Exp. Med. 141: 287-296.

3. Perlmann, P., and H. Perlmann. 1970. Contactual lysis of antibody-coated chicken erythrocytes by purified lymphocytes. Cell. Immunol. 1: 300-315.

4. Winchester, R. J., S. M. Fu, T. Hoffman, and H. G. Kunkel. 1975. IgG on lymphocyte surfaces; technical problems and the significance of a third cell population. J. Immunol. 114: 1210-1212.

5. Wisloff, F., S. S. Froland, and T. E. Michaelsen. 1974. Antibody-dependent cytotoxicity mediated by human Fc- receptor bearing cells lacking markers for $\mathrm{B}$ and $\mathrm{T}$ lymphocytes. Int. Arch. Allerg. Appl. Immunol. 47: 139-154.

6. Ferrarini, M., L. Moretta, R. Abrile, and M. L. Durante. 1975. Receptors for IgG molecules on human lymphocytes forming spontaneous rosettes with sheep red cells. Eur. J. Immunol. 5: 70-72.

7. Huber, H., and H. H. Fudenberg. 1968. Receptor sites of human monocytes for IgG. Int. Arch. Allerg. Appl. Immunol. 34: 18-31.

8. Wong, L., and J. D. Wilson. 1975. The identification of Fc and C3 receptors on human neutrophils. J. Immunol. Methods. 7: 69-76.

9. Jondal, M., H. Wigzell, and F. Auiti. 1973. Human lymphocyte subpopulations: classification according to surface markers and/or functional characteristics. Transplant. Rev. 16: 163-195.

10. Kovithavongs, T., G. Rice, K. L. Thong, and J. B. Dossetor. 1975. Effector cell activity in antibody mediated cell dependent immune lysis. II. Evidence for different populations of effector cells for different targets. Cell. Immunol. 18: 167-175.

11. Nelson, D. L., B. M. Bundy, H. E. Pitchon, R. M Blaese, and W. Strober. 1976. The effector cells in human peripheral blood mediating mitogen-induced cellular cytotoxicity and antibody-dependent cellular cytotoxicity. J. Immunol. 117: 1472-1481.

12. Ting, A., and P. I. Terasaki. 1974. Influence of lymphocyte-dependent antibodies on human kidney transplants. Transplantation (Baltimore). 18: 371-373.

13. Pollack, S., G. Heppner, R. J. Brawn, and K. Nelson. 1972. Specific killing of tumor cells in vitro in the presence of normal lymphoid cells and sera from hosts immune to the tumor antigens. Int. J. Cancer. 9: 316-323.

14. Calder, E. A., W. J. Penhale, D. McLeman, E. W Barnes, and W. J. Irvine. 1973. Lymphocyte-dependent antibody-mediated cytotoxicity in Hashimoto's thyroiditis. Clin. Exp. Immunol. 14: 153-158.

15. Zawodnik, S. A., G. D. Bonnard, and E. Gautier. 1976. Antibody-dependent cell-mediated destruction of human erythrocytes sensitized in ABO and Rhesus fetal-maternal incompatibilities. Pediatr. Res. 10: 791-796.

16. Blaese, R. M., E. Rosenberg, and J. Wunderlich. 1972 Evidence of two functionally distinct lymphocyte populations in man. In Microenvironmental Aspects of Immunity. B. D. Jankovic and K. Isakovic, editors. Plenum Press, New York. 315-320.

17. Wisloff, F., and S. S. Froland. 1973. Antibody-dependent lymphocyte-mediated cytotoxicity in man: no requirement for lymphocytes with membrane-bound immunoglobulin. Scand. J. Immunol. 2: 151-157.

18. Rachelefsky, G. S., P. R. McConnachie, A. J. Ammann, P. I. Terasaki, and E. R. Stiehm. 1975. Antibody dependent lymphocyte killer function in human immunodeficiency diseases. Clin. Exp. Immunol. 19: 1-9.

19. Cooper, M. D., W. P. Faulk, H. H. Fudenberg, R. A. Good, W. Hitzig, H. Kunkel, F. S. Rosen, M. Seligmann, J. Soothill, and R. J. Wedgwood. 1973. Classification of primary immunodeficiencies. N. Engl. J. Med. 288: 966-967.

20. Schiff, R. I., R. H. Buckley, R. B. Gilbertsen, and R. S. Metzgar. 1974. Membrane receptors and in vitro responsiveness of lymphocytes in human immunodeficiency. $J$. Immunol. 112: 376-386.

21. Buckley, R. H., R. B. Gilbertsen, R. I. Schiff, E. Ferreira, S. O. Sanal, and T. A. Waldmann. 1976. Heterogeneity of lymphocyte subpopulations in severe combined immuno- 
deficiency. Evidence against a stem cell defect. J. Clin. Invest. 58: 130-136.

22. Boyum, A. 1968. Isolation of mononuclear cells and granulocytes from human blood. Scand. J. Clin. Lab. Invest. 21 (Suppl. 97): 77-89.

23. Kaplow, L. S. 1965. Simplified myeloperoxidase stain using benzidine dihydrochloride Blood. 26: 215-219.

24. Zucker-Franklin, D. 1974. The percentage of monocytes among "mononuclear" cell fractions obtained from human blood. J. Immunol. 112: 234-240.

25. Chess, L., R. P. MacDermott, and S. F. Schlossman. 1974. Immunologic functions of isolated human lymphocyte subpopulations. J. Immunol. 113: 1113-1121.

26. Trinchieri, G., M. DeMarchi, W. Mayr, M. Savi, and R. Ceppellini. 1973. Lymphocyte antibody lymphocytolytic interaction (LALI) with special emphasis on HL-A. Transplant. Proc. 5: 1631-1649.

27. Brier, A. M., L. Chess, and S. F. Schlossman. 1975. Human antibody-dependent cellular cytotoxicity. Isolation and identification of a sub-population of peripheral blood lymphocytes which kill antibody-coated autologous target cells. J. Clin. Invest. 56: 1580-1586.

28. Chess, L., R. Evans, R. E. Humphreys, J. L. Strominger, and S. F. Schlossman. 1976. Inhibition of antibodydependent cellular cytotoxicity and immunoglobulin synthesis by an antiserum prepared against a human $B$ cell Ia-like molecule. J. Exp. Med. 144: 113-122.

29. Nelson, D. L., W. Strober, L. D. Abelson, B. M. Bundy, and D. L. Mann. 1977. Distribution of alloantigens on human Fc receptor-bearing lymphocytes: the presence of $B$ cell alloantigens on sIg-positive but not sIg-negative lymphocytes. J. Immunol. 118: 943-946.

30. Papamichael, M., and A. Temple. 1975. Characterization of the human effector cell causing antibody-mediated cytotoxicity. Clin. Exp. Immunol. 20: 459-467.

31. Pape, G. R., M. Troye, and P. Perlmann. 1977. Characterization of cytolytic effector cells in peripheral blood of healthy individuals and cancer patients. J. Immunol. 118: 1919-1924.

32. Dickler, H. B., and H. G. Kunkel. 1972. Interaction of aggregated $\gamma$-globulin with B lymphocytes. J. Exp. Med. 136: $191-196$.

33. Greenberg, A. H., L. Hudson, L. Shen, and I. M. Roitt. 1973. Antibody-dependent cell-mediated cytotoxicity due to a "null" lymphoid cell. Nat. New Biol. 242: $111-113$.

34. Gale, R. R., J. Zighelboim, R. C. Ossorio, and J. L. Fahey. 1975. A comparison of human lymphoid cells in antibody-dependent cellular cytotoxicity (ADCC). Clin. Immunol. Immunopathol. 3: 377-384.

35. Wilfert, C. M., R. H. Buckley, T. Mohannakumar, J. F. Griffith, S. L. Katz, J. K. Whisnant, P. A. Eggleston, M. Moore, E. Treadwell, M. N. Oxman, and F. S. Rosen. 1977. Persistent and fatal Echovirus infection in patients with agammaglobulinemia. N. Engl. J. Med. 296: 1485-1489. 